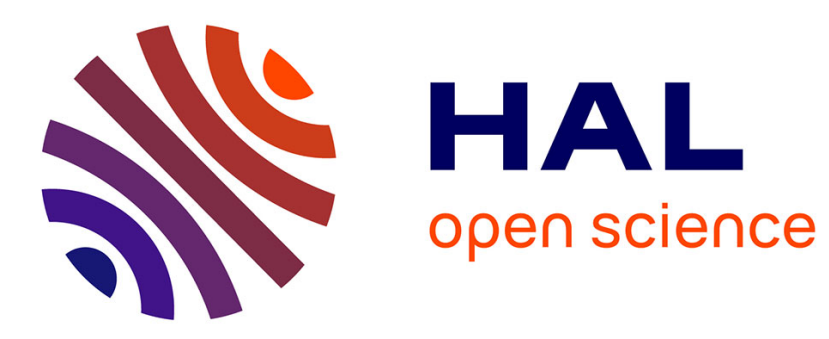

\title{
The origin of the reflexive prefix in Rgyalrong languages \\ Guillaume Jacques
}

\section{To cite this version:}

Guillaume Jacques. The origin of the reflexive prefix in Rgyalrong languages. Bulletin of the School of Oriental and African Studies, 2010, 73 (2), pp.261 -268. halshs-00531157

\section{HAL Id: halshs-00531157 https://shs.hal.science/halshs-00531157}

Submitted on 2 Nov 2010

HAL is a multi-disciplinary open access archive for the deposit and dissemination of scientific research documents, whether they are published or not. The documents may come from teaching and research institutions in France or abroad, or from public or private research centers.
L'archive ouverte pluridisciplinaire HAL, est destinée au dépôt et à la diffusion de documents scientifiques de niveau recherche, publiés ou non, émanant des établissements d'enseignement et de recherche français ou étrangers, des laboratoires publics ou privés. 
The origin of the reflexive prefix in Rgyalrong languages. ${ }^{i}$

Guillaume JACQUES, Université Paris Descartes, CRLAO

Abstract: In the Sino-Tibetan family, reflexivity is either not expressed on the verb as in Chinese or Tibetan or expressed by means of a 'middle' marker as in Dulong or Kiranti languages. Among the morphologically rich languages of this family, only Rgyalrong languages have distinct and unambiguous reflexive and reciprocal markers on the verb.

This paper shows that the reflexive prefix in Rgyalrong languages has two possible origins. It could come from a fusion of the third person singular marker and the root meaning 'self' or alternatively come from the free third person pronoun. Both hypotheses are compatible with our understanding of Rgyalrong historical phonology.

Keywords: Rgyalrong ; Japhug ; reflexive ; reciprocal ; Tangut ; Yukaghir ; grammaticalization 
In the Sino-Tibetan family, reflexive and reciprocal meanings are often not expressed on the verb (Chinese, LB, Tibetan etc.). Some languages do have middle markers which, alongside other functions, can express reflexivity (as in Dulong/Rawang, see LaPolla 1996, 2000, LaPolla and Yang 2004), but among the morphologically rich languages of this family, only Rgyalrong ${ }^{\mathrm{ii}}$ languages have distinct and unambiguous reflexive and reciprocal markers on the verb.

The aim of this paper is to examine the origin and the evolution of the reciprocal and reflexive forms in Rgyalrong languages.

\section{Reciprocal}

Let us first examine the reciprocal form. As was described in Jacques and Chen (2007:904), the Japhug reciprocal form is made by adding the intransitivizing prefix a(anti-causative) to the reduplicated stem of the transitive verb. Here are two pairs of examples:

$$
\begin{array}{ll}
\text { ndza } & \text { 'to eat' } \\
\text { a-ndzu-ndza } & \text { 'to eat each other' } \\
\text { nurutsa } & \text { 'to be jealous of' } \\
\text { a-nurutsur-tsa } & \text { 'to be jealous of one another' }
\end{array}
$$

It is a fully productive process, which can be applied to most transitive verbs. The subject of a reciprocal verb must always be plural, and this form never has any reflexive interpretation: a-ndzu-ndza cannot mean 'to eat oneself'.

\section{Reflexive}

All known Rgyalrong languages have a cognate reflexive prefix: Japhug zy $\gamma^{\gamma}$-, Situ

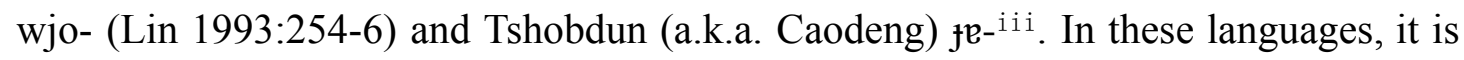
the last derivational prefix in the prefixal chain, and its isolation in the ST family, or even Qiangic, betrays a late origin. In this section, we will first present the syntactic functions of this prefix in Japhug, then investigate possible phonological reconstructions for this prefix in proto-Rgyalrong, and finally propose an explanation for the origin of this prefix and its grammaticalization process.

\subsection{Syntactic functions}

In Rgyalrong languages, the distinction between transitive and intransitive verbs is a very rigorous one. In particular, transitive verbs have a special -a- prefix in the Aorist when both argument are third person and no inverse prefix is present ${ }^{\text {iv }}$. Therefore, it is always straightforward to determine whether a verb is intransitive, transitive or labile.

Adding the reflexive prefix decreases the verb valency by one argument, and transforms a transitive verb into an intransitive one. In the following example, the verb 'to transform' su-rpa (itself the causative form of the verb 'to become') is transitive so that its Aorist form takes the -a- transitive prefix, while the reflexive zy $\gamma$-su'transform oneself into' is intransitive, and bears no -a- prefix (*nu-a-zy $\gamma$-suwould be ungrammatical).

$$
\text { u-tcu nu ckrru nu-a-su-rpa }
$$




$\begin{array}{lll}\text { 3SG-son DET } & \text { Muntjac AOR-3>3-CAUS-become } \\ \text { uzo } & \text { xtut } & \text { nu-zyr-SU-rpa } \\ \text { 3SG } & \text { wild cat } & \text { AOR-REFL-CAUS-become }\end{array}$

She changed her son into a muntjac, and herself into a wild cat (Lobzang 53)

When the original verb is the causative form of a transitive verb, and has therefore three arguments, the reflexive indicates coreference between the agent of the causative form and the patient of the original transitive verb:

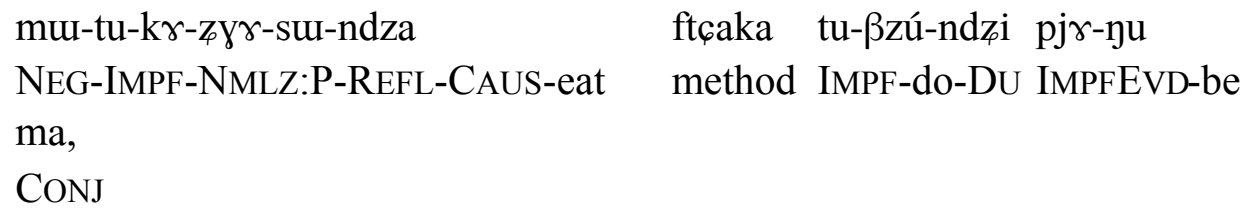

They did their best not to be eaten (by the cat) (The mouse, the bird and the cat 17)

This example litterally means 'They ${ }_{\mathrm{i}}$ acted in such a way not to let (the cat) eat themselves ${ }_{i}$.

When the original verb is a simple transitive, the result is a morphologically intransitive verb. However, we find in some texts a few cases where the ergative appears with the unique argument of a reflexive verb, which seems to indicate that the verb preserves some degree of semantic transitivity:

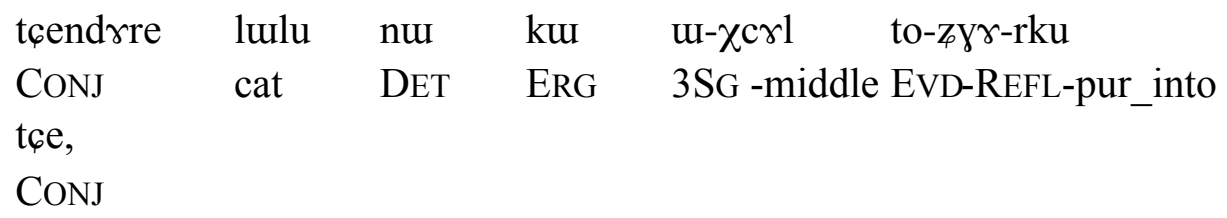

No affix similar to Japhug zyr- in both form and meaning is to be found in any other ST language, even within the Qiangic group. The rest of the paper will investigate the origin of this prefix.

\subsection{Phonological reconstruction}

In Jacques $(2004,2008)$, no reconstruction in proto-Japhug was provided for the initial cluster $\mathrm{z} \gamma$ - found in the reflexive prefix zy $\gamma$-. The correspondence $z \gamma-::$ wj- $:: \mathfrak{y}$ is unknown elsewhere in the reconstructible Rgyalrongic vocabulary and we need to posit a special reconstruction.

The Situ form wjo- could suggest to reconstruct here a group ${ }^{*} w j-$ in protoRgyalrong, which would have simplified to $\mathrm{f}$ - in Tshobdun and metathesized to *jw-, then $\mathrm{zY}^{-}$- in Japhug. However, we have already used a reconstruction *wj- in proto-

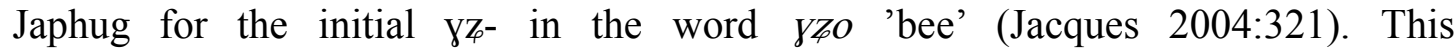
reconstruction was proposed to account for the Zbu cognate wujê. In order to be able to explain both forms, we suggest two possibilities.

First, we could give two distinct reconstructions form Japhug yz- and zy-: 


\begin{tabular}{|c|c|c|c|c|}
\hline Proto-Japhug & Japhug & Situ & Tshobdun & Zbu \\
\hline *wว-j- & YZ- & & & wuj- \\
\hline${ }^{*}$ wj- & zy- & wj- & $\mathrm{j}^{-}$ & \\
\hline$*_{\mathrm{W}}$ & $\gamma^{-}$ & w- & V- & V- \\
\hline$*_{\mathrm{j}}$ & Z- & j- & $y^{-}$ & j- \\
\hline
\end{tabular}

Table 1: Origins of Japhug $\mathrm{\gamma z}^{-}$- and $\mathrm{zy}$ - in proto-Japhug.

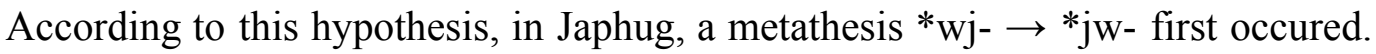
Other examples of metatheses are found in Japhug, such as $* \mathrm{kp}-\rightarrow \beta \gamma-$ (Jacques 2008: 373). After this change, a new $* w j-$ cluster was created by the fusion of a $* u-$ presyllable $*_{\mathrm{u}-\mathrm{j}-} \rightarrow{ }^{*} \mathrm{wj}-$.

Alternatively, given the limited number of examples, one could argue that the proto-Japhug cluster ${ }^{*} w j-$ had a different evolution in affixes and in nouns.

In any case, reconstructing * wj- seems the best solution to account for this cluster. Situ appears to have preserved the original pronunciation.

As for the rime of the prefix, we find the unusual correspondence $\gamma:: 0:: \mathrm{e}$. It could be interpreted in several ways. First, one could argue that the proto-Japhug form had a central vowel *e, as in Japhug and Tshobdun, and that it became o in Situ due to the influence of the rounded preinitial -w-. Another possibility to consider is that the central vowel appeared due to morphological vowel alternation, as attested in Japhug (Jacques 2004: 196) and Tshobdun (Sun 1998: 109). Vowel alternations such as o $\rightarrow \gamma$, $\mathrm{a} \rightarrow \mathrm{r}$ etc, are common in compound words, such as:

\begin{tabular}{|c|c|c|c|c|}
\hline Basic form & Meaning & Compound form & Meaning & Alternation \\
\hline ४६O & bee & $\begin{array}{l}\text { yъr-ndza } \\
\text { 'bee food' }\end{array}$ & $\begin{array}{l}\text { Agastache } \\
\text { rugosus }^{v}\end{array}$ & $\mathrm{o} \rightarrow \gamma$ \\
\hline trmdzu & thorn & $\begin{array}{l}\text { trmdzr-rgi } \\
\text { 'thorn fir' }\end{array}$ & thistle & $\mathrm{u} \rightarrow \mathrm{\gamma}$ \\
\hline sto & broad bean & $\begin{array}{l}\text { stas-put } \\
\text { 'little broad bean' }\end{array}$ & pea & ов $\rightarrow$ ав \\
\hline
\end{tabular}

Table 2: Examples of vowel alternation in nominal morphology.

In Jacques (2004, 2008)'s reconstruction, it was shown that Situ o has two origins: proto-Rgyalrong *ay and ${ }^{*}$, which change to o and u respectively in Japhug. Given the fact that both Japhug o and $u$ change become $\gamma$ through vowel alternation, two reconstructions seem possible for the reflexive prefix in proto-Rgyalrong: either *wjan- or *wjo-.

\subsection{Etymology}

Of these two possible reconstructions, *wjay- is the only one which allows us to find an etymology for the reflexive prefix.

Two grammatical words can be reconstructed as *jay in proto-Rgyalrong: one is

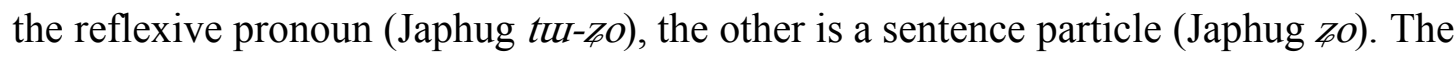
reflexive *jay is probably related to Tibetan rang; the correspondence $\mathrm{j}:: \mathrm{r}$ is also 
found in the word 'bee' considered above (proto-Rgyalrong *u-jay, Tibetan sbrang).

Since no account of the function of the intensifier particle $z o$ has appeared in print yet, it seems necessary to briefly describe how this particule is used. $\Varangle o$ appears mainly in the following contexts:

A. In combination with an adverb of degree :

izo i-zimkham tce, pra wuma zo drn tce,

We 1PL-country CONJ birdmuch INT NP:many CONJ

There are many birds in our country.

(7)

$\begin{array}{llllll}\text { a-wa } & \text { nu } & \text { pu-pu-nu } & \text { n } & \text { phasrslay } & \text { nu } \\ \text { 1SG-father } & \text { DET } & \text { RED-PASIMPF-be } & \text { CONJ } & \text { Pha seng gling } & \text { DET } \\ \text { zdurthur } & \text { zo } & \text { a-pu-yu n } & \text { nu-sna } & \\ \text { barely enough } & \text { INT } & \text { IRR-IMPF-be CONJ } & \text { IMPF-good } & \\ \text { As for my father, Phasengling is just acceptable (Gesar, 8) } & \end{array}$

B. in combination with a ideophone or a manner adverb

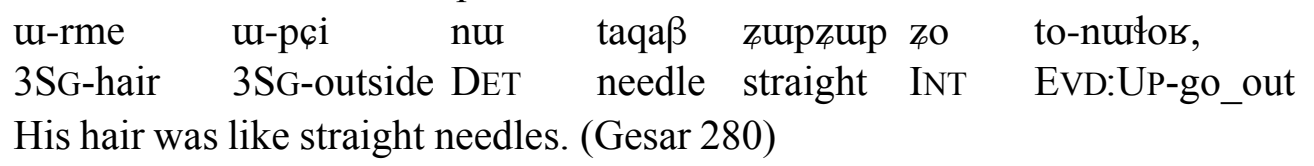

C. An entire proposition expressing the manner:

(The frog) was jumping left and right, and she could not tread him down (the frog, 206)

D. A proposition expressing place or time:

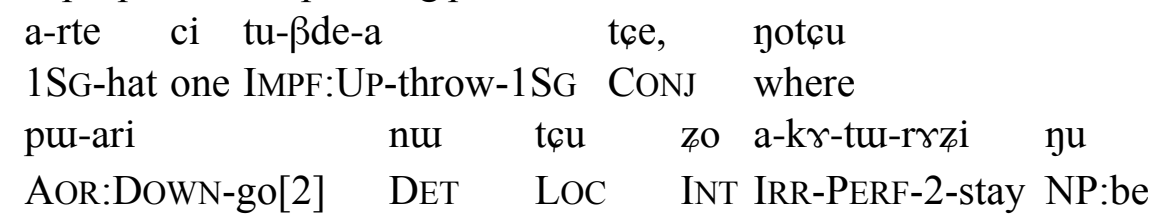

(Padmasambhāva said) "I will throw this hat of mine upwards, and you will live in the place where it fell down." (Gesar, 30).

Although the particle $z o$ is very frequent, it is not compulsory in any of these constructions. It is probably to be compared to the Tibetan conjunction yang / kyang, usually translated as 'also, even'. It is therefore unrelated to the reflexive, even though they are homonymous in all Rgyalrong languages.

We will present here two hypotheses to explain the origin of the reflexive prefix.

\subsection{1 $\quad$ Reflexive pronoun}

The reflexive prefix could be derived from the reflexive pronoun, incorporated 
into the verb and then grammaticalized as a reflexive marker. The ${ }^{*} \mathrm{w}$ - element in ${ }^{*} \mathrm{w}$ jay- could be interpreted as the third person pronoun ${ }^{\mathrm{vi}}$. As we proposed above in 2.2, the morpheme boundary between ${ }^{*} \mathrm{w}$ and $*_{\text {-jay }}$ blocked the regular change ${ }^{*}$ wj- $\rightarrow$ *jw- in Japhug.

In other Qiangic languages such as Tangut, the cognate reflexive pronoun ${ }^{\text {vii }}$ is also prefixed to the verb. It is already grammaticalized to a certain extent, as even if a

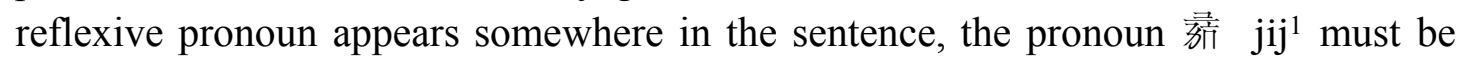
prefixed directly to the verb. It is therefore very common in texts for this character to appear two times in the same sentence:

\begin{tabular}{|c|c|c|c|c|}
\hline 紊 & 竞 & 紊 & 蕧 & 從 \\
\hline $\mathrm{jij}$ & ljụ & jij & sja & kiẹj \\
\hline 1.36 & 2.52 & 1.36 & 1.20 & 2.53 \\
\hline EFL & body & REFL & kill & want \\
\hline
\end{tabular}

As she wanted to kill herself (Jacques 2007:16, 4.2-4.3)

However, the exact grammaticalization path is not entirely clear, as the presence of the third person pronominal element ${ }^{*} \mathrm{w}$ - has not received any explanation.

It is not uncommon for a pronominal marker to be generalized as a reflexive marker. For instance, in Kolyma Yukaghir (Maslova to appear §5.4), the reflexive prefix met- is derived from the first person singular pronoun, though it is used whatever the person and number of the subject:

$$
\begin{aligned}
& \text { tudel met-juö-j } \\
& \text { he REFL-see-3SG:INTR } \\
& \text { He is looking at himself. }
\end{aligned}
$$

A closely related language, Tundra Yukaghir, preserves the older pattern where the reflexive verbs have a pronominal prefix coreferent with the subject. In Rgyalrong, the third person singular, not the first person would have been generalized. However, it is not obvious why both the third person pronoun and the reflexive pronoun would have had to be incorporated. The reflexive pronoun alone could have fulfilled this function, without any need for a second grammaticalization.

\subsubsection{Full third person pronoun}

This second hypothesis is not entirely different from the first one. Rather than arguing that two subsequent grammaticalizations occurred (first the reflexive pronoun, then the third person), we alternatively propose that the third person free pronoun could have been incorporated.

In Rgyalrong, the free pronouns are generally composed of a pronominal prefix and a root going back to *jay (-jo in Situ, -zo in Japhug, -ji? in Tshobdun). In Japhug and Tshobdun (Sun 1998:113), all pronouns follow this structure except third person dual and plural. In Situ only the third person pronoun wo-jo follows this structure, and in $\mathrm{Zbu}$ the second person singular form noje? seems to be the only one with a reflex of the *-jay element. 


\begin{tabular}{|c|c|c|c|c|c|}
\hline & \multicolumn{2}{|l|}{ Japhug } & Tshobdun & Situ & Zbu \\
\hline $1 \mathrm{Sg}$ & a-zo & a- & e-ji? & ya & yə? \\
\hline $2 \mathrm{Sg}$ & nr-zo & nr- & ne-yi? & no & nəje? \\
\hline $3 \mathrm{Sg}$ & U-Zo & u- & o-fi? & wə-jo & aphe? \\
\hline 1Du Incl & \multirow[t]{2}{*}{ tढ़i-zo } & \multirow[t]{2}{*}{ tçi- } & tsə-łə-ni? & ndzo & \multirow[t]{2}{*}{ tढ़--ni } \\
\hline 1Du Excl & & & tsə-fə & yə-ndze & \\
\hline $2 \mathrm{Du}$ & ndzi-z̧o & ndzi- & ndzə-fə-ni? & nd3o & ndzreni \\
\hline $3 \mathrm{Du}$ & zr-ni & ndzi- & fe-ni? & wə-jo-ndzəs & aphe?ni \\
\hline 1P1 Incl & \multirow[t]{2}{*}{ ji-zo } & \multirow[t]{2}{*}{ ji- } & jə-jə-re? & jo & \multirow[t]{2}{*}{ ygere? } \\
\hline 1P1 Excl & & & jə-fə & yə-ne & \\
\hline $2 \mathrm{Pl}$ & nul-zo & nu- & nə-fə-re? & no & nere? \\
\hline $3 \mathrm{Pl}$ & za-ra & nu- & fe-re? & wə-jo-ne & aphere? \\
\hline
\end{tabular}

Table 3: Personal pronouns in Rgyalrong languages.

The third person dual and plural forms (Japhug $\not \gamma \gamma-n i$ / $z a-r a$, Tshobdun $f \mathcal{E}$-ni? and $f E-r E$ ?) are formed of the - ni and -ra dual and plural clitics suffixed to the same *jan stem. However, this stem underwent vowel alternation in both languages (see above, Table 2). viii Besides, in Japhug, vowel harmony assimilated $\gamma$ to $a$, due to the presence of $a$ in the second syllable in za-ra.

This pervasive *jay element could well be the reflexive stem. In many languages, including English, intensive pronouns are formed by combining personal pronouns with reflexive (myself, himself etc). However, other languages form intensive pronouns with an adverbial unrelated to the reflexive. In French, for instance, they are formed by adding même 'even, also, same' to the strong pronoun (moi-même, luimême etc). Therefore, it would be equally possible to interpret the *jay element in the Rgyalrong pronouns as being cognate to the intensive particle $z o$ rather than to the reflexive form.

Whatever the exact origin of the *jay element, the alternative hypothesis we propose to explain the origin of the reflexive prefix in Rgyalrong would be the following: the third person pronoun *wu-jay would have been prefixed to the verb and incorporated, becoming the reflexive marker in all Rgyalrongic languages, as the first person pronoun in Kolyma Yukaghir.

A problem with this hypothesis is that it would imply that the grammaticalization of the reflexive occured after the creation of the bimorphemic pronouns in Rgyalrong, relatively late in the history of the Rgyalrong languages. In the prefixal chain, the reflexive is the last derivational prefix, the furthest one from the verb root. Nevertheless, it is still closer to the verb root than any flexionnal prefix. Unless an externalization of inflection occurred (Haspelmath 1993), it is hard to explain how the incorporated pronoun could have been inserted between the inflexional prefixes and the verb stem.

\section{Conclusion}

In this paper, we have proposed two possible hypotheses to account for the origin of the reflexive prefix in Rgyalrong languages. Its phonological reconstruction is 
relatively straightforward, but its exact origin is ambiguous: it could be either the third person pronoun singular or a reflexive pronoun. Further studies in the historical morphology of other Qiangic languages may help to decide which hypothesis is most probable.

The Rgyalrong reflexive prefix reconstructed in this article as *wjay- perhaps arose as a response to the loss of the Middle marker suffix found in Dulong/Rawang (cu/-ci), Kiranti and West Himalayish (discovered by LaPolla 1996).

Haspelmath Martin. 1993. The diachronic externalization of inflection. Linguistics 31.2: 279-309.

Jacques, Guillaume. 2004. Phonologie et morphologie du Japhug (rgyalrong), thèse de doctorat, université Paris VII-Denis Diderot.

http://tel.archives-ouvertes.fr/tel-00138568/fr/

Jacques, Guillaume. 2007. Textes tangoutes I, Nouveau recueil sur l'amour parental et la piété filiale, München: Lincom Europa.

Jacques, Guillaume. (向柏霖) 2008. Jiarongyu yanjiu. Beijing: Minzu chubanshe.

Jacques, Guillaume and Chen Zhen 2007. Chabaohua de bujiwu qianzhui ji xiangguan wenti, Language and Linguistics 8.4, 883-917.

LaPolla, Randy 1996. Middle Marking in Tibeto-Burman. Proceedings of the Fourth International Symposium on Languages and Linguistics: Pan-Asiatic Linguistics (January 8-10, 1996), Volume 5: 1940-1954.

LaPolla, Randy 2000. Valency-changing derivations in Dulong/Rawang, in Changing valency : Case studies in transitivity, ed. by R.W.M. Dixon and Alexandra Y. Aikhenvald, Cambridge: Cambridge University Press.

LaPolla, Randy J. and Yang Jiangling. 2004. Reflexive and Middle Marking in Dulong-Rawang. Himalayan Linguistics Journal 2. 1-13.

Lin Youjing and Luoerwu 2003. Chabao jiarongyu dazanghua de quxiang qianzhui ji dongci cigan bianhua, Minzu yuwen 4, 19-29.

Lin Xiangrong 1993. Jiarongyu yanjiu. Chengdu: Sichuan Minzu chubanshe.

Maslova Elena, Reciprocals in Yukaghir languages, To appear in Vladimir P. Nedjalkov (Ed.), Typology of reciprocal constructions.

Nedjalkov Vladimir. 2004. Reciprocal constructions in Turkic languages, International symposium on typology of the argument structure and grammatical relation in languages spoken in Europe and Nord and Central Asia, LENCA-2, Kazan State University, May 11-14.

Sun, Jackson T.-S. 1998. Nominal Morphology in Caodeng rGyalrong. Bulletin of the Institute of History and Philology 69.1:103-149.

Sun, Jackson T.-S. 2000. Parallelisms in the verb morphology of Sidaba rGyalrong and Guanyinqiao in rGyalrongic. Language and Linguistics 1.1:161-190.

Sun, Jackson T.-S. 2003. Caodeng rGyalrong. Sino-Tibetan Languages, ed. by Graham Thurgood and Randy J. LaPolla. London:Routledge, pp. 490-502.

Sun, Jackson T.-S. 2006. Caodeng jiarongyu de guanxiju, Language and Linguistics, 7.4: 905-933.

Sun, Jackson T.-S. and Shidanluo 2002. Caodeng jiarongyu yu "rentong dengdi" 
xiangguan de yufa xianxiang, Language and Linguistics, 3.1:79-99.

${ }^{i}$ I would like to thank Nathan Hill for his help correcting an earlier version of this paper, Randy LaPolla for useful comments and Chen Zhen 陳珍 and her family for teaching me Japhug. The following abbreviations are used: A (agent of transitive verb), AOR (aorist), CAUS (causative), CONJ (conjunction), DEM (demonstrative), DET (determiner), DU (dual), ERG (ergative), EVD (evidential), IMPF (imperfective), IMP (imperative), INF (infinitive), INT (intensifier), INTR (intransitive), INV (inverse), IRR (irrealis), LB (Lolo-Burmese), LOC (locative), NEG (negation), NMLZ (nominalization), NP (non past), P (patient of transitive verb), PASIMMPF( past imperfective), PERF (perfective), PL (plural), RED (reduplication), REFL (reflexive), S (only argument of intransitive verb), SG (singular), ST (Sino-Tibetan), 1 (first person), 2 (second person),3 (third person), [2] stem 2.

ii There are four Rgyalrong languages: Japhug/Chabao 茶堡, Zbu/Ribu/Showu 日部/修梧, Tshobdun/Caodeng 草登, Situ/Eastern Rgyalrong 四土, spoken in Rngaba (Aba 阿壩)

Autonomous County, Sichuan, China. For a general overview of Rgyalrong dialects, see Lin (1993:411-625) and Sun (2000:162-169). Rgyalrong languages belong to the Qiangic branch of ST, which also comprises the dead Tangut language (cited in example 11), Lavrung, Horpa/Shangzhai, Pumi, Muya, Queyu, Qiang and perhaps a few other languages of western Sichuan such as Zhaba, Guiqiong, Ersu, Namuyi and Shixing.

iii See for instance Sun 2006: tə-ko-jp-sə-rqo (Perf-Nmlz:A:Inv-Refl-Caus-hug2).

iv This prefix fuses with the Aorist directional prefix, see Lin and Luo (2003), Jacques and Chen (2007).

$\checkmark$ Better known under its Chinese name 蕉香 huoxiang.

vi Cognate to the possessive prefix Japhug u-, Situ wə-, Zbu və-.

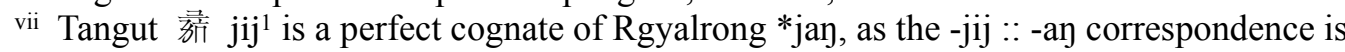
regular.

viii The alternation was $o \rightarrow \gamma$ in Japhug and $i \rightarrow \mathfrak{v}$ in Tshobdun. 